\title{
PEREMPUAN PECINTA ALAM SEBAGAI WUJUD EKOFEMINISME
}

\author{
Ni Made Anggita Sastri Mahadewi \\ Program Studi Sosiologi \\ Fakultas Ilmu Sosial dan Ilmu Politik, Universitas Udayana \\ Email: anggitasastrimahadewi@unud.ac.id
}

\begin{abstract}
ABSTRAK
Tulisan ini berupaya menjelaskan peran perempuan pada organisasi Mahasiswa Pecinta Alam (Mapala) Wanaprastha Dharma, dalam melakukan pelestarian alam. Pada umumnya kegiatan pecinta alam memiliki resiko tinggi dan menuntut kekuatan fisik yang besar, yang identik dimiliki oleh laki-laki. Namun anggota perempuan organisasi Mapala Wanaprastha Dharma mampu melakukan berbagai kegiatan pelestarian alam yang beresiko dengan kekuatan fisik yang memadai. Fenomena tersebut merupakan gambaran konsep ekofeminisme yang menekankan bahwa antara perempuan dan alam memiliki keterkaitan yang tidak dapat dipisahkan, baik oleh kondisi alam itu sendiri maupun oleh stereotipe tentang tubuh perempuan yang dianggap lebih lemah dari laki-laki. Anggota perempuan Mapala Wanaprastha Dharma secara struktural organisasi menempati posisi tinggi, antara lain sebagai ketua umum, sekretaris, maupun ketua pelaksana kegiatan. Melalui penjelasan dalam tulisan ini keterlibatan perempuan dalam pelestarian alam baik yang diimplementasikan secara langsung di lapangan, maupun tidak langsung yakni melalui perencanaan dan program kerja, menunjukan bahwa menjadi hal yang sulit untuk memisahkan perempuan dengan alam.
\end{abstract}

Kata kunci: Mapala Wanaprastha Dharma, perempuan pecinta alam, ekofeminisme

\begin{abstract}
This paper seeks to explain the role of women in the Nature Lovers Student Organization (Mapala) Wanaprastha Dharma, in doing nature conservation. In general the activities of nature lovers have a high risk and demand great physical strength, which is identical to that of men. However, female members of the Mapala Wanaprastha Dharma organization were able to carry out various natural conservation activities which were at risk with adequate physical strength. This phenomenon is an illustration of the concept of eco-feminism which emphasizes that between women and nature has a connection that cannot be separated, both by natural conditions themselves and by stereotypes about the bodies of women who are considered weaker than men. The Mapala Wanaprastha Dharma female member structurally occupies a high position, among others as general chairman, secretary, and chief executive of activities. Through the explanation in this paper, the involvement of women in nature conservation, both directly implemented in the field, and indirectly through planning and work programs, shows that it is difficult to separate women from nature. Keywords: Mapala Wanaprastha Dharma, female nature lover, eco-feminism
\end{abstract}

\section{PENDAHULUAN}

Ekofeminisme adalah suatu gerakan yang menghubungkan antara feminisme dengan ekologi. Istilah ini pertama kali diperkenalkan oleh penulis Prancis Françoise d' Eaubonne dalam bukunya, Le Féminisme ou la Mort (1974). Ekofeminisme membahas di satu pihak, eksploitasi dan dominasi perempuan terhadap lingkungan; dan di pihak lain, berpendapat bahwa sesungguhnya ada hubungan historis antara perempuan dan alam. Para Ekofeminis percaya bahwa 
hubungan ini digambarkan melalui nilai timbal balik 'perempuan' secara tradisional, pemeliharaan dan kerjasama, yang terjadi baik di kalangan perempuan maupun di alam. Perempuan dan alam juga bersatu dalam sejarah mereka, yang sama-sama pernah mengalami penindasan oleh masyarakat patriarki.

Menurut Francoise d'Eaubonne dalam bukunya Le Féminisme ou la Mort (1974), ekofeminisme menghubungkan penindasan dan dominasi kelompok pada semua aspek (perempuan, orang kulit berwarna, anak-anak, orang miskin) dengan penindasan dan penguasaan alam (hewan, tanah, air, udara, dan lain-lain.) Dalam buku itu, Francoise berpendapat bahwa penindasan, penguasaan, eksploitasi, dan penjajahan dari masyarakat patriarki Barat, telah secara langsung menyebabkan kerusakan lingkungan yang tidak dapat dipulihkan. Françoise dalam pokok pikirannya selalu mendorong penghapusan semua ketidakadilan sosial, bukan hanya ketidakadilan terhadap perempuan dan lingkungan. (Adams, 2007)

Tradisi ekofeminisme sesungguhnya tergambar dari sejumlah wacanawacana dengan pengaruh besar di dunia, diantaranya, Women and Nature (Susan Griffin 1978), The Death of Nature (Carolyn Merchant 1980) dan Gyn/Ecology (Mary Daly 1978). Teks-teks tersebut membantu untuk memahami suatu konteks ekofeminisme, terutama dalam mendorong hubungan antara dominasi oleh laki-laki terhadap perempuan dan dominasi budaya pada alam. Dari teks-teks ini aktivisme pada feminis tahun 1980-an, kemudian mengaitkan ide-ide ekologi dan lingkungan. Misalnya, konferensi untuk perempuan yang ditujukan untuk hidup di bumi, protes menentang uji coba nuklir dan militerisme, sampai pada penyampaian cerita perjalanan para perempuan pendaki gunung di seluruh dunia dalam mengupayakan dan menyebarkan pesan-pesan cinta terhadap alam semesta.

Bentuk protes, perjuangan dan gerakan perempuan khususnya yang langsung bersentuhan dengan alam semakin berkembang di era milenial ini. Cerita tentang perempuan pendaki gunung menjadi pengantar dari berbagai perjuangan perempuan lainnya seperti kisah Aleta Baun atau yang lebih akrab Mama Aleta yang berjuang dalam menjaga alamnya. Aleta Baun memulai perjuangannya menyelamatkan bumi Mollo di Kabupaten Timor Tengah Selatan (TTS), NTT, sejak 1999. Dia menolak penambangan marmer di Desa Fatukoto. Putri dari sorang Amaf atau dalam adat Mollo merupakan struktur yang berperan serupa DPRD - ini menghadapi perusahaan tambang milik pengusaha dari ibu kota. Kiprahnya itu membuatnya berurusan dengan aparat dan bupati setempat. Dia bahkan masuk dalam daftar pencarian orang (DPO) kepolisian setempat dan paling dicari. Pada 2006, Aleta Baun masih dianggap musuh oleh bupati setempat karena dianggap bertanggung jawab atas aksi ratusan warga. Terutama, para perempuan yang menduduki tambang marmer dengan menenun selama dua bulan di Desa Fatumnasi dan Kuanoel. Mereka menenun di depan batu besar yang menjadi sumber hidup mereka, dengan tuntutan penghentian tambang milik pengusaha Jakarta itu.

Mama Aleta dan masyarakat adat Mollo berjuang lebih dari 13 tahun untuk menutup tambang marmer. Mereka mempercayai alam bagian tubuh manusia. "Batu sebagai tulang, tanah sebagai daging, air sebagai darah dan hutan sebagai kulit, paru-paru dan rambut." Menurutnya, merusak alam seperti merusak tubuh sendiri. Hutan memiliki fungsi menjaga lahan dan melindungi sumber-sumber air. Seperti kulit dan rambut yang melindungi daging dan darah. Jika hutan rusak, tanah 
akan tidak subur. Gunung batu juga menyimpan air, di bawahnya selalu ada sumber air. Saat ini masyarakat di sekitar Mollo membentuk kelompok perempuan penenun dan pertanian organik, serta kelompok ternak. Mereka menghijaukan daerah sekitar sumber air dengan tanaman asli, membangun lumbung pangan dan memperbanyak pewarna alami untuk tenun. Meski perusahaan tambang berhasil diusir, namun perjuangan mereka belum selesai (Asti, 2017).

Keyakinan yang dimiliki oleh Mama Aleta dimana merusak hutan sama dengan merusak kehidupan sendiri juga diyakini oleh perempuan-perempuan yang tergabung dalam organisasi Mahasiswa Pecinta Alam (Mapala) Wanaprastha Dharma (WD) Universitas Udayana. Anggota perempuan Mapala WD melakukan berbagai kegiatan penyelamatan lingkungn sama seperti yang anggota laki-laki lakukan, tidak jarang kegiatan tersebut dilakukan di medan yang ekstrim atau membutuhkan kekuatan fisik yang mumpuni. Hal tersebut tidak menjadi hambatan bagi anggota perempuan Mapala WD untuk turut serta menjaga kelestraian alam, bahkan para anggota perempuan mampu menduduki posisi penting seperti ketua umum, ketua pelaksana kegiatan dan lain sebagainya. Karya tulis ini memang tidak menyajikan cerita tentang perjuangan besar perempuan seperti yang dilakukan oleh Aleta Baun, namun tulisan ini akan memperlihatkan bahwa perubahan tentang stereotipe mengenai perempuan yang tidak bisa setara dengan laki-laki dapat dipatahkan melalui gerakan-gerakan sederhana yang dimulai dari lingkungan sendiri.

\section{METODE PENELITIAN}

Karya tulis ini disusun berdasarkan hasil penelitian, dimana metode yang digunakan adalah metode penelitian kualitatif dengan jenis deskriptif-eksploratif. Metode dan jenis penelitian tersebut dipilih karena penelitian ini berupaya untuk menggali secara mendalam dan mendeskripsikan secara mendetail mengenai pengimplementasian gerakan ekofeminisme yang dilakukan oleh anggota perempuan Mapala WD. Data dikumpulkan dengan teknik wawancara mendalam, observasi dan studi literature. Observasi dilakukan dengan terjun langsung ke lapangan terlibat dalam kegiatan di Mapala WD. Wawancara mendalam dilakukan dengan informan yakni Ketua Umum Mapala WD Tahun 2011 yang diketuai oleh perempuan; para ketua pelaksana kegiatan di Mapala WD khususnya para ketua perempuan; dan anggota Mapala WD baik perempuan maupun laki-laki. Para informan tersebut dipilih karena memberikan gambaran yang spesifik mengenai keterlibatan perempuan dalam kegiatan pelestarian alam. Selanjutnya, data di analisis melalui tiga tahap yakni reduksi data, analisis data dan penarikan kesimpulan. Reduksi data dilakukan dengan memilih data-data yang dibutuhkan untuk menjawab permasalahan penelitian, data hasil observasi, wawancara dan studi dokumen direduksi secara berkesinambungan. Data yang telah direduksi selanjutnya dianalisis menggunakan konsep ekofeminisme, sehingga jawaban yang didapatkan releven. Tahap berikutnya penarikan kesimpulan.

\section{HASIL DAN PEMBAHASAN}

Ortner (dalam Susilo, 2012 : 120) menyatakan bahwa tidak mudah bagi perempuan untuk memutuskan kedekatannya dengan alam. Hampir seluruh 
kebudayaan menunjukkan bahwa perempuan secara praktis dan emosional lebih dekat dengan alam dibandingkan laki-laki. Ekofeminisme merupakan bagian dari gerakan feminis yang spesifik mengenai permasalahan perempuan dan lingkungan, dimana perempuan memiliki andil besar dalam upaya penyelamatan alam. Karren J. Warren (dalam Tong, 2010 : 360) mengatakan perempuan 'dinaturalisasi' artinya perempuan disamakan dengan alam saat mengalami eksploitasi terhadap diri dan tubuhnya. Alam 'difeminisasi, disamakan dengan perempuan saat alam 'diperkosa', 'ditaklukkan', untuk memenuhi kebutuhan manusia, bahkan saat alam dipuja dan dihormati sebagai 'ibu pertiwi'. Kondisi seperti ini dapat dijumpai pada kehidupan perempuan pada zaman dahulu yang ruang geraknya masih sangat terbatas, biasanya perempuan pada masa sebelum era revolusi hanya melakukan kegiatan rumah tangga.

Pernyataan Ortner dan para tokoh ekofeminis tersebut, didukung oleh data yang dimiliki oleh Mapala WD (2014). Setiap tahun terjadi peningkatan jumlah anggota perempuan dalam organisasi tersebut. Pada tahun 2010 anggota yang tergabung terdiri dari 2 orang perempuan dan 4 orang laki-laki. Pada tahun 2011 hanya terjadi penambahan satu anggota perempuan, menjadi 3 orang perempuan dan 12 orang laki-laki. Sedangkan pada angkatan tahun 2012 terjadi kenaikan yang signifikan yakni terdiri dari 30 orang perempuan dan 30 orang laki-laki. Data tersebut menunjukan bahwa perempuan semakin sadar bahwa dirinya memiliki keterikatan tersendiri dengan alam. Ada empat faktor yang melatarbelakangi anggota perempuan Mapala WD melakukan gerakan penyelamatan alam yaitu, sebagai berikut.

\section{- Faktor Peraturan Organisasi}

Mapala WD sebagai organisasi resmi memiliki etika dan nilai-nilai organisasi sebagai landasan dalam melakukan setiap kegiatan yakni; 1). Kode Etik Pecinta Alam se-Indonesia, 2). Ikrar Pecinta Alam se-Bali, dan 3). Ikrar Mapala WD. Selain memiliki etika dan nilai-nilai Mapala WD mempunyai peraturan-peraturan yang ditetapkan dalam Musyawarah Istimewa Anggota yang membahas beberapa hal sebagai berikut; 1). AD/ART, 2). Kebijakan organisasi dan pembagian tugas, 3). Jenjang keanggotaan dan atribut yang berhak dipakai, 4). Program kerja dan penjabaran aktivitasnya, dan 5). Etika dan sanksi-sanksi.

Selain itu Mapala WD juga memiliki kurikulum pendidikan tersendiri bagi para anggotanya yang dibagi ke dalam lima jenjang yaitu, pelatihan tingkat dasar (PTD), masa bimbingan (Mabim), pelatihan tingkat lanjut (PTL), latihan search and rescue (LATSAR), dan pelatihan instruktur (Instructor Development Course IDC). Mapala WD melibatkan seluruh anggota baik laki-laki maupun perempuan dalam penyusunan peraturan-peraturan tersebut, sehingga tidak ada anggota yang merasa terdiskriminasi karena perbedaan gender.

Pendekatan gender memastikan bahwa perempuan seperti juga laki-laki, mempunyai akses yang sama terhadap sumber-sumber dan kesempatan. Terdapat empat faktor utama sebagai berikut.

- Konsep dalam kebijaksanaan dan program harus mencerminkan pengalaman laki-laki dan perempuan. 
- Perempuan sama halnya dengan laki-laki harus dipastikan ikut mempunyai akses dan mempunyai kontrol terhadap program.

- Dalam formulasi kebijaksanaan perencanaan maupun implementasinya perempuan dan laki-laki harus ikut berpartisipasi.

- Dalam evaluasi dan monitoring harus ada sistem yang memperlihatkan dampak program terhadap keduanya (Setiadi dan Kolip, 2011 : 875).

\section{- Faktor Motivasi}

Motivasi menjadi salah satu faktor yang melatarbelakangi para perempuan anggota Mapala WD melakukan gerakan penyelamatan alam. Motivasi terbentuk oleh dua faktor yakni, faktor internal dan faktor eksternal. Faktor internal motivasi terbentuk karena adanya kebutuhan dan/atau keinginan dari individu itu sendiri. Lebih lanjut dijelaskan bahwa bumi oleh nenek moyang disebut sebagai Ibu Bumi, Ibu Pertiwi atau Ibu Shinta. Pertiwi (Bahasa Sanskerta: prthivī matā) berarti Dewi atau Ibu Bumi (atau dalam Bahasa Indonesia Ibu Pertiwi). Dalam Kitab Rgveda, Ibu Pertiwi ini adalah antonim dari Bapak Angkasa karena bumi dan langit seringkali disapa sebagai sebuah pasangan. Namun, mengapa bumi itu disebut sebagai $I b u$ ? Ini tak lain adalah karena bumi menjadi tempat di mana manusia lahir dan ke mana jasad mereka kelak berbaring. Bumi yang memberikan kehidupan terhadap seluruh makhluk di dunia ini. Makanan dan minuman manusia ini tak lain berasal dari sari-sari bumi dalam wujud flora, fauna, maupun air. Itu artinya bahwa bumi mempunyai peran sebagai yang melahirkan, menumbuhkan dan memelihara segala makhluk.

Pemahaman ini selaras dengan dengan isi Kitab Kejadian 1:11 dan 24, yang menyebutkan: Berfirmanlah Allah: "Hendaklah tanah menumbuhkan tunas-tunas muda, tumbuh-tumbuhan yang berbiji, segala jenis pohon buah-buahan yang menghasilkan buah yang berbiji, supaya ada tumbuh-tumbuhan di bumi." Dan jadilah demikian. Berfirmanlah Allah: "Hendaklah bumi mengeluarkan segala jenis makhluk yang hidup, ternak dan binatang melata dan segala jenis binatang liar." Dan jadilah demikian. (Budi, 2016)

Oleh sebab itu, bagaikan perempuan yang menjadi penopang seluruh keluarga, keberadaan bumi juga memiliki peran serupa bagi kelanjutan hidup seluruh ciptaan. Bagaikan tubuh perempuan yang harus dijaga, sebagai penopang hidup manusia, bumi pun harus dijaga kelestariannya. Konsep Ibu Bumi seperti ini ternyata tidak hanya ada di Indonesia. Sejumlah negara yang memiliki konsep ini pernah mengadakan Konferensi Ibu Bumi di Bolivia pada 2010. Dalam konferensi ini, sejumlah negara mendeklarasikan komitmen untuk memberikan kepada bumi hak untuk "bernapas". Para peserta menyerukan agar menghargai alam karena hidup kita bersumber dari alam (Wahyu, 2017).

Beberapa gerakan penyelamatan lingkungan yang dilatarbelakangi oleh motivasi, seperti aksi bersih tebing Uluwatu, aksi bersih Sungai Badung, Mount Batur Revegetation, konservasi mangrove, Seminar Nasional Konservasi Kawasan Pesisir, dan aksi hijau Bali Majegau yang akan dibahas secara rinci dalam pembahasan berikutnya. Faktor eksternal seperti kondisi lingkungan yang memprihatinkan dan juga adanya kerja sama dengan lembaga atau organisasi 
lingkungan lainnya. Faktor eksternal tersebut dapat mempengaruhi faktor internal dimana dengan mempertimbangkan kondisi lingkungan, isu lingkungan yang sedang berkembang.

\section{Gerakan Penyelamatan Lingkungan Mapala WD yang Melibatkan Perempuan}

Gerakan Bersih Lingkungan

- Aksi Bersih Tebing Uluwatu

Aksi bersih tebing Uluwatu merupakan kegiatan rutin yang diadakan setiap tahun oleh Mapala WD sebagai bentuk kepedulian terhadap kondisi kebersihan di lingkungan Pura Luhur Uluwatu. Kondisi di areal tebing yang banyak sampah merusak keindahan dan kesucian areal pura. Pada kegiatan ini anggota yang bertugas tidak hanya laki-laki, anggota perempuan juga ikut membersihkan tebing dengan bergantung dengan peralatan yang telah disediakan.

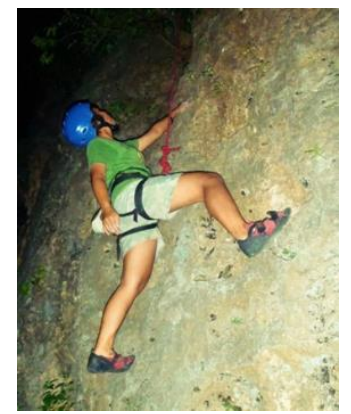

Anggota Perempuan Mapala WD Berlatih Panjat Tebing untuk Aksi di Tebing Uluwatu. Sumber: Mapala WD,2013

- Aksi Bersih Sungai Badung

Keberadaan sungai Badung sangat dibutuhkan di Denpasar, karena lahan kosong semakin sedikit sehingga daerah resapan air berkurang, yang berakibat terjadinya banjir saat musim hujan. Berbagai fungsi sungai bertolak belakang dengan yang terjadi di lapangan, sungai dijadikan tempat pembuangan sampah, sehingga menumpuk dan aliran sungai menjadi terhalang sampah dan berbau tidak sedap. Sebagai bentuk kepeduliannya Mapala WD melakukan Aksi Bersih Sungai Badung, dengan melibatkan seluruh anggota baik laki-laki maupun perempuan dan juga masyarakat sekitar yang ingin berpartisipasi. 


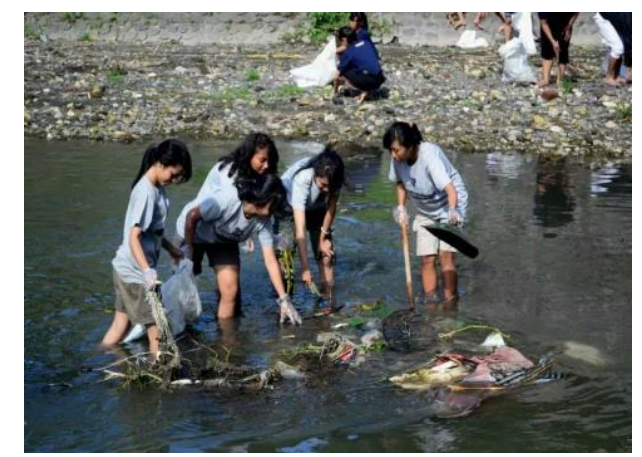

Anggota Mapala WD sedang Mengumpulkan

Sampah di Sungai Badung

Sumber: Mapala WD, 2014

\section{Gerakan Konservasi}

- Mount Batur Revegetation

Mount Batur Revegetation 2013 yakni sebuah kegiatan yang bertujuan untuk membentuk sebuah vegetasi baru, penghijauan lahan kembali pada lahan kritis. Kegiatan ini terselenggara berkat kerjasama antara Mapala WD, Universitas Yamaguchi, Takino Filter Inc., Bali Mori Kai, UPT Laboratorium Sumber Daya Genetika dan Biologi Molekuler Universitas Udayana, dan didukung oleh Bali Agro Bag. Dalam aksi ini Mapala WD berperan sebagai pelaksana dan peserta, yang diikuti oleh laki-laki dan perempuan perwakilan dari pihak-pihak yang bekerja sama dan juga seluruh anggota Mapala WD.

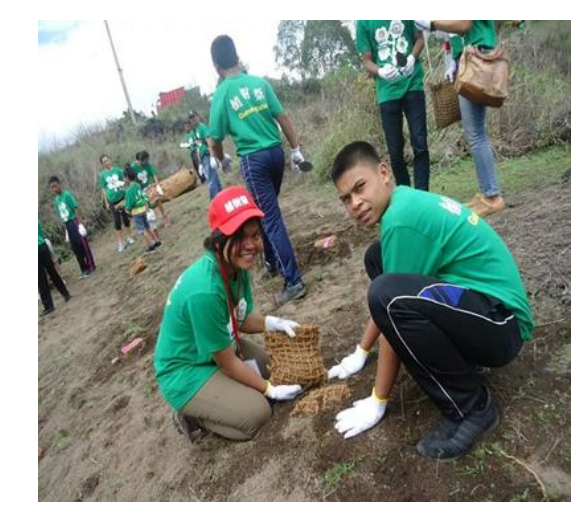

Anggota Mapala WD sedang Menanam Menggunakan Ubur-Ubur dan Serabut Kelapa Sumber: Mapala WD, 2013

- Konservasi Mangrove

Dinas Kehutanan Provinsi Bali tahun 2013 menyebutkan, luas kawasan bakau di Bali adalah $1.786 \mathrm{Ha}$, tetapi dari luas tersebut tidak sepenuhnya 
ditanami bakau. Maka dari itu Mapala WD menyelenggarakan kegiatan ini, yang mengundang Siswa Pecinta Alam (Sisipala) se-Bali untuk berpartisispasi dalam aski ini. Aksi ini dilaksanakan di sekitar Pulau Serangan, diharapkan dengan adanya kegiatan ini masyarakat menjadi peduli untuk menjaga keberlangsungan dan kebersihan kawasan bakau. Perempuan dan laki-laki dilibatkan dalam aksi ini seluruhnya ikut serta menanam bibit bakau.

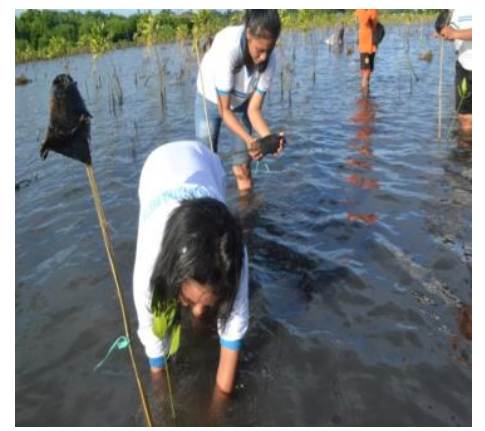

Peserta Sispala Menanam Bibit Bakau Sumber: Mapala WD, 2010

\section{Gerakan Edukasi Lingkungan}

- Seminar Nasional Konservasi Kawasan Pesisir

Kegiatan yang dilaksanakan pada tanggal 20-21 April 2013, merupakan bentuk gerakan penyelamatan lingkungan laut yang menjadikan terumbu karang sebagai objeknya. Terdapat rangkaian acara dalam kegiatan ini yakni seminar nasional dan kunjungan lapangan untuk mempraktekkan apa yang telah dipelajari saat seminar. Peserta dapat menanam sendiri terumbu karang di meja-meja pembibitan yang telah disediakan oleh panitia, selain itu peserta juga dapat melihat langsung terumbu karang budidaya di kawasan pantai Pulau Serangan dengan menyelam. Mapala WD berperan sebagai penyelenggara dalam kegiatan ini dan pemberi materi cara menanam bibit terumbu karang saat kegiatan kunjungan lapangan.

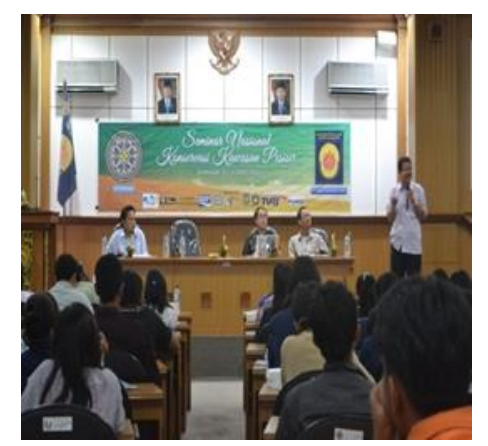

Kegiatan Seminar Konservasi Kawasan Pesisir \& Penanaman Bibit Terumbu Karang Sumber: Mapala WD, 2013 
Mapala WD memberikan gambaran kecil perempuan dan alam memiliki keterikatan yang tak dapat dipisahkan. Menjadi perempuan, menjadi laki-laki, memiliki tanggung jawab yang sama besarnya untuk menjaga alam.

\section{SIMPULAN}

Gerakan feminisme pada dasarnya adalah sebuah upaya menuntut adanya persamaan hak antara kaum perempuan dan laki-laki. Namun, adanya tuntutan persamaan hak ini hendaknya juga dibarengi dengan adanya upaya kerjasama yang baik antara kaum perempuan dan lelaki dalam sebuah hubungan kemitraan. Kaum lelaki bukanlah musuh kaum perempuan, demikian juga sebaliknya. Kaum perempuan juga bukanlah budak kaum lelaki, demikian juga sebaliknya. Maka, perlu adanya hubungan dan kerjasama di antara keduanya - sebagai yang samasama menjadi penghuni muka bumi, yakni: sebuah hubungan dan kerjasama yang setara, seimbang, dan saling memanusiakan.

Dari pemahaman ini, maka gerakan ekofeminisme juga bertitik-tumpu pada terwujudnya sebuah hubungan dan kerjasama yang setara, seimbang, dan saling memanusiakan di antara kaum perempuan dan lelaki, yakni untuk sama-sama memiliki tanggung jawab yang sama terhadap kelestarian bumi. Kaum perempuan dan lelaki hendaknya mampu saling membina, bekerjasama dan saling mengingatkan akan tanggung jawab bersama ini, yaitu: melestarikan hidup.

\section{Referensi}

Adams, Carol. 2007. Ecofeminism and the Sacred. Continuum

Anonim. 2013. Pelibatan Perembuan dalam Pengelolaan Sumber Daya Alam untuk Meningkatkan Kualitas Hidup. (dalam: http://readersblog.mongabay.co.id/rb/2013/05/23/pelibatan-perempuandalam-pengelolaan-sumber-daya-alam-untuk-meningkatkan-kualitaslingkungan-hidup/)

Cahyono,Budi.2016.

Ekofeminisme.

(dalam: https://gkjw.or.id/essay/ekofeminisme/)

Dian, Asti. 2017. Mama Aleta Fund: Untuk Perempuan Pejuang dan Penyelamat Alam. (dalam: https://www.mongabay.co.id/2017/03/14/mama-aletafund-untuk-perempuan-pejuang-dan-penyelamat-alam/)

Setyawan, Wahyu Eka. 2017. Review Singkat Pengantar Ekofeminisme. (dalam: https://medium.com/lingkaran-solidaritas/review-singkat-pengantarekofeminisme-2f05c1a669a9)

Rusmini, Oka. 2010. Tempurung. Jakarta: Grasindo.

Putnam Tong, Rosemarie. 2010. Feminist Thought: Pengantar Paling Komprehensif kepada Arus Utama Pemikiran Feminis. Yogyakarta:Jalasutra.

Handayani, Trisakti \& Sugiarti. 2008. Konsep dan Teknik Penelitian Gender. Malang : Universitas Muhammadiyah Malang Pres 
Mapala Wanaprastha Dharma. 2013. Pengenalan Organisasi Mapala Wanaprastha Dharma.

Setiadi, Elly M. \& Usman Kolip. 2011. Pengantar Sosiologi: Pemahaman Fakta Dan Gejala Permasalahan Sosial: Teori, Aplikasi, dan Pemecahannya. Jakarta : Kencana

Susilo, Rachmad K. Dwi. 2012. Sosiologi Lingkungan. Jakarta : PT Raja Grafindo Persada 